\title{
PENGEMBANGAN PERANGKAT PEMBELAJARAN PENEMUAN TERBIMBING BERBANTUAN MIKROSKOP SEDERHANA UNTUK MELATIHKAN KETERAMPILAN PROSES SAINS DAN PEMAHAMAN KONSEP MATERI SISTEM ORGANISASI KEHIDUPAN PADA SISWA SMP
}

\author{
Indah Hartanti ${ }^{1)}$, Raharjo ${ }^{2)}$, Tarzan Purnomo ${ }^{3)}$ \\ 1)Program Studi Pendidikan Sains, Program Pascasarjana Universitas Negeri Surabaya, \\ ${ }^{2)}$ Dosen Program Studi Pendidikan Sains, Program Pascasarjana Universitas Negeri Surabaya \\ ${ }^{3)}$ Dosen Program Studi Pendidikan Sains, Program Pascasarjana Universitas Negeri Surabaya \\ e-mail: indah.hartanti2@gmail.com
}

\begin{abstract}
Abstrak: Penelitian ini bertujuan menghasilkan perangkat pembelajaran IPA model pembelajaran Penemuan Terbimbing Berbantuan Mikroskop Sederhana untuk melatihkan keterampilan proses sains dan pemahaman konsep siswa. Perangkat pembelajaran yang dikembangkan meliputi Silabus, RPP, LKS, Media Mikroskop Sederhana, Tes Keterampilan proses sains, dan Tes Pemahaman Konsep. Jenis penelitian adalah penelitian pengembangan perangkat pembelajaran. Model pengembangan perangkat yang digunakan adalah model pengembangan perangkat Model 4D. Ujicoba perangkat pembelajaran dilakukan di SMP Negeri 2 Losari Brebes dengan menggunakan rancangan One Group Pretest-Posttest Design. Instrumen yang digunakan dalam penelitian ini berupa lembar validasi perangkat pembelajaran, lembar pengamatan keterlaksanaan RPP, aktivitas siswa, lembar penilaian keterampilan proses sains dan pemahaman konsep, lembar observasi sikap, dan angket. Teknik analisis data menggunakan analisis deskriptif kuantitatif dan kualitatif. Hasil penelitian menunjukkan bahwa perangkat pembelajaran yang dikembangkan valid dan dapat digunakan. Keterlaksanaan pembelajaran $100 \%$ terlaksana dengan kategori terlaksana sangat baik Aktivitas siswa yang menonjol adalah melakukan pengamatan/ penyelidikan menggunakan mikroskop sederhana. Keterampilan proses sains dan pemahaman konsep siswa mengalami peningkatan dengan nilai $\mathrm{N}$-Gain dalam kategori sedang. Respon positif siswa terhadap pembelajaran sebesar $86 \%$ dengan kategori sangat kuat. Berdasarkan hasil analisis data dapat disimpulkan bahwa perangkat pembelajaran dengan Penemuan Terbimbing Berbantuan Mikroskop Sederhana layak (valid, praktis, dan efektif) digunakan untuk melatihkan keterampilan proses sains dan pemahaman konsep siswa.
\end{abstract}

Kata Kunci : Perangkat Pembelajaran, Penemuan Terbimbing, Mikroskop Sederhana, Keterampilan Proses Sains, Pemahaman Konsep.

Abstract: This study aims to produce science instructional sets Guided Discovery Model Assisted Microscope Simple to facilitate science process skills and students' understanding concepts. The instructional sets developed are Syllabus, Lesson Plans, Worksheets, Simple Microscope Media, Science Process Skills Test, and Concepts Understanding Test. This type of research is the instructional sets development research. The instructional sets development model used is the instructional sets development of 4D Model. The experiment of instructional sets was conducted at SMP Negeri 2 Losari Brebes by using One Group Pretest-Posttest Design. The instruments used in this study were the validation sheets of instructional sets, the observation sheets of the implementation of Lesson Plans, the students' activities, the assessment sheets of science process skills and concepts understanding, the observation sheets of attitude and the questionnaires. Data analyzing technique used were descriptive analysis of quantitative and qualitative. The result of this research shows that the instructional sets developed are valid and can be used. The implementation of instruction are $100 \%$ done with very good category done. The most dominant of students' activity is doing observation/investigation using simple microscope. Science process skills and students' concepts understanding increases by value of N-Gain at middle category. The positive response of students towards the instruction is $86 \%$ with very strong category. Based on the results of data analysis, it can be concluded that the instructional sets with Guided Discovery Assisted Simple Microscope are feasible (valid, practical, and effective) to use to facilitate science process skills and students' concepts understanding.

Keywords: Instructional Sets, Guided Discovery, Simple Microscope, Science Process Skills, Concepts Understanding.

\section{PENDAhuluaN}

Undang-Undang No 20 Tahun 2003 tentang Sistem Pendidikan Nasional menyatakan bahwa pendidikan adalah usaha sadar dan terencana untuk mewujudkan suasana belajar dan proses pembelajaran agar peserta didik secara aktif mengembangkan potensi dirinya untuk

Pengembangan Perangkat Pembelajaran Penemuan

Terbimbing Berbantuan Mikroskop Sederhana ........... 
memiliki kekuatan spiritual keagamaan, pengendalian diri, kecerdasan, akhlak mulia, serta keterampilan yang diperlukan dirinya, masyarakat, bangsa dan negara (Sanjaya, 2006).

Ilmu Pengetahuan Alam (IPA) menurut Ibrahim (2012) didefinisikan sebagai proses ilmiah, sikap ilmiah dan produk ilmiah. IPA sebagai proses memandang IPA bersifat dinamis, ibarat sebuah roda selalu berputar dalam rangka pengembangan ilmu. IPA sebagai sikap menuntut siswa jujur, teliti, skeptis dan disiplin. Sikap juga ditunjukkan oleh kemampuan seseorang untuk memiliki keterampilan sosial. IPA sebagai produk terdiri atas hukum, prinsip, prosedur teori, konsep, fakta dan informasi.

Tujuan pembelajaran IPA di Sekolah Menengah Pertama diantaranya agar peserta didik memiliki kemampuan: 1) meningkatkan keyakinan terhadap kebesaran Tuhan Yang Maha Esa berdasarkan keberadaan, keindahan, dan keteraturan alam ciptaanNya, 2) mengembangkan pemahaman tentang berbagai gejala alam, konsep dan prinsip IPA yang bermanfaat dan dapat diterapkan dalam kehidupan sehari-hari, 3) mengembangkan rasa ingin tahu, sikap positif, dan kesadaran terhadap adanya hubungan yang saling mempengaruhi antara IPA, lingkungan, tehnologi dan masyarakat, 4) meningkatkan pengetahuan, konsep, dan keterampilan IPA sebagai dasar untuk melanjutkan pendidikan ke jenjang selanjutnya (Kemendikbud, 2013).

Tujuan pembelajaran akan terwujud apabila proses pembelajaran berjalan dengan baik. Pembelajaran yang baik dipengaruhi oleh beberapa faktor, seperti faktor guru, siswa, lingkungan, kurikulum, sarana dan pra sarana dan lain sebagainya (Suryosubroto,1982). Begitu halnya tujuan pembelajaran IPA akan tercapai jika semua faktor atau komponen pembelajaran IPA dalam kondisi baik.

Berdasarkan hasil wawancara yang dilakukan kepada seorang guru IPA kelas VIIG di SMP Negeri 2 Losari Kabupaten Brebes Jawa Tengah pada tanggal 15 Februari 2016 didapatkan informasi bahwa pada saat mengajarkan materi Sistem Organisasi Kehidupan, metode yang dipakai adalah metode ceramah, sedangkan media yang dipakai hanya buku guru dan buku siswa. Hasil belajar siswa berupa nilai ulangan harian, diperoleh data dari 42 siswa hanya 9 orang yang mendapatkan nilai $\geq \mathrm{KKM}$. Padahal KKM yang ditetapkan adalah $\geq 2,66$.

Melihat kenyataan kurang maksimalnya nilai hasil belajar tersebut diyakini karena sulit bagi siswa untuk memahami konsep IPA apabila hanya dari ceramah. Hal ini tidak sejalan dengan anjuran Kemendikbud (2014) yakni model pembelajaran yang dikembangkan dalam
Kurikulum 2013 ini berbasis pada konstruktivis. Penekanan pengajaran kontruktivis pada siswa sebagai siswa yang aktif.

Metode yang digunakan selain masih konvensional (metode ceramah) kemungkinan yang lain adalah karena media yang digunakan kurang bervariasi, hanya dari buku guru dan buku siswa. Hal tersebut menyebabkan siswa kurang terbantu, merasa bosan dan tidak tertarik dengan materi pelajaran. Padahal Imamah (2012) menjelaskan bahwa pembelajaran IPA adalah pembelajaran yang paling menyenangkan karena siswa dapat belajar melalui alam sekitar yang tentunya sudah tidak asing bagi mereka. Siswa diajak untuk bersentuhan langsung dan mengenal objek belajar di sekitar siswa, gejala, permasalahan (penerapan proses sains), menelaahnya dan menemukan simpulan atau konsep tentang sesuatu yang dipelajarinya.

Materi Sistem Organisasi Kehidupan tercantum dalam Kompetensi Dasar (KD) 3.4 Mendeskripsikan keragaman pada sistem organisasi kehidupan mulai dari tingkat sel sampai organisme, serta komposisi utama penyusun sel dan KD 4.4 Melakukan pengamatan dengan bantuan alat untuk menyelidiki struktur tumbuhan dan hewan. Karakteristik materi pada Sistem Organisasi Kehidupan mempelajari keragaman mulai tingkat sel, jaringan, organ, sistem organ sampai organisme. Keragaman meliputi struktur, bentuk dan fungsi. Struktur di dalamnya berupa bagian-bagian yang menyusun struktur tersebut. Struktur dan bentuk tidak cukup diberikan hanya dengan metode ceramah. Materi sel merupakan materi cukup sulit bagi siswa, karena materi yang tersaji pada buku-buku paket cenderung abstrak, sedangkan perkembangan mental siswa kelas VII SMP berada pada fase transisi dari kongkrit ke formal/abstrak (Depdiknas, 2004).

Proses pembelajaran IPA menekankan pada pemberian pengalaman langsung untuk mengembangkan kompetensi. Melalui pembelajaran IPA, siswa dapat memperoleh pengalaman langsung, sehingga dapat menambah kekuatan untuk menerima, menyimpan, dan menerapkan konsep yang telah dipelajari. Pembelajaran materi Sistem Organisasi Kehidupan akan lebih menyenangkan dan bermakna apabila siswa diajak langsung mengamati terhadap objek yang dikaji. Implementasi Kurikulum 2013 menekankan pada aktivitas $5 \mathrm{M}$ yang meliputi Mengamati, Menanya, Mengumpulkan Data, Mengasosiasi dan Mengkomunikasikan. Melihat KD yang telah di uraikan di depan, maka peneliti berasumsi dengan siswa diajak melakukan keterampilan proses sains yang meliputi mengamati, menanya, menggunakan alat/bahan untuk 
melakukan pengamatan/penyelidikan, menginterprestasi data, menyimpulkan dan mengkomunikasikan terhadap obyek kajian maka tujuan KD akan tercapai. Melalui keterampilan proses sains diharapkan siswa mampu menemukan sendiri konsep-konsep penting. Seiring dengan Permendikbud No 58 Tahun 2014 bahwa Ilmu Pengetahuan Alam (IPA) berkaitan dengan cara mencari tahu tentang alam secara sistematis, sehingga IPA bukan hanya penguasaan kumpulan pengetahuan yang berupa fakta-fakta, konsep-konsep, atau prinsip-prinsip saja tetapi juga suatu proses penemuan. Proses pembelajarannya menekankan pada pemberian pengalaman langsung untuk mengembangkan kompetensi agar menjelajahi dan memahami alam sekitar secara ilmiah.

Keterampilan proses yang dilatihkan pada pembelajaran tentunya membutuhkan model yang tepat. Model penemuan terbimbing (Guided Discovery) merupakan pilihan yang cocok dalam pembelajaran keterampilan proses sains pada usia siswa kelas VII SMP. Agar pembelajaran model penemuan terbimbing dapat terlaksana maka diperlukan perangkat pembelajaran yang mendukungnya, untuk itu perlu dikembangkan perangkat pembelajaran berbasis penemuan terbimbing. Sintak dalam penemuan terbimbing memuat siswa untuk melakukan keterampilan proses sain, sehingga penemuan terbimbing seiring dengan keterampilan proses sains.

Pembelajaran Sistem Organisasi Kehidupan yang dimulai dari tingkat sel akan optimal jika menggunakan media yang tepat. Penggunaan alat bantu pengamatan seperti mikroskop menjadi sangat penting dalam kegiatan pengamatan/penyelidikan. Pengamatan langsung terhadap objek asli, misalnya sel dan jaringan, merupakan solusi untuk mengkonkretkan pemahaman siswa terhadap objek tersebut serta memberikan pengalaman belajar yang lebih bermakna (Trisnayanti, 2010). Sel sebagai unit struktural dan fungsional terkecil dari makhluk hidup memiliki ukuran yang sangat kecil. Untuk mengetahui bentuk, struktur, dan bagian-bagian lain yang terdapat dalam sel, maka mikroskop merupakan satu-satunya gerbang pembuka misteri tentang sel.

Mikroskop merupakan alat optik yang digunakan untuk melihat benda-benda yang sangat kecil pada jarak dekat (Tipler, 2001). Ketersediaan mikroskop cahaya konvensional (Model Student) yang ada di SMPN 2 Losari tidak sebanding dengan jumlah siswa yang akan menggunakan mikroskop tersebut, sehingga diperlukan mikroskop alternatif yang bisa membantu siswa dalam mempelajari materi pada Sistem Organisasi Kehidupan. Mikroskop alternatif yang dijadikan solusi adalah mikroskop sederhana yang terbuat dari bahan-bahan di sekitar yang mudah didapat seperti tempat CD, DVD, laser mainan anak (sebagai lensa objektif dan sumber cahaya), baut, mur. Mikroskop sederhana ini yang dimodifikasi dengan sebuah kamera handpone (sebagai lensa okuler dan pembentukan bayangan atau gambar).

Media Mikroskop Sederhana menjadi penting dalam mempelajari Sistem Organisasi Kehidupan, karena media tersebut dapat memberi pengalaman langsung kepada siswa untuk belajar mengamati objek yang sangat kecil seperti sel, jaringan dan organ dari tubuh organisme dengan jelas dan detail. Dengan begitu keterampilan proses sains menggunakan mikroskop sederhana dan mempresentasikan data akan terlatih, yang pada akhirnya pemahaman konsep mengenai Materi Organisasi Kehidupan juga bertambah. Sudjana dan Rivai (2002) menyatakan bahwa dengan media pembelajaran bahan pengajaran akan lebih jelas maknanya sehingga dapat lebih dipahami oleh siswa, dan kemungkinan siswa menguasai tujuan pengajaran lebih baik.

Berdasarkan latar belakang masalah tersebut, peneliti mengembangkan dan menerapkan perangkat pembelajaran penemuan terbimbing berbantuan mikroskop sederhana untuk melatihkan keterampilan proses sains dan pemahaman konsep pada materi Sistem Organisasi Kehidupan melalui penelitian yang berjudul "Pengembangan Perangkat Pembelajaran Penemuan Terbimbing Berbantuan Mikroskop Sederhana untuk Melatihkan Keterampilan Proses Sains dan Pemahaman Konsep Materi Sistem Organisasi Kehidupan Pada Siswa SMP",

\section{METODE PENELITIAN}

Penelitian ini tergolong jenis penelitian pengembangan, karena dalam penelitian ini dikembangkan perangkat pembelajaran penemuan terbimbing berbantuan mikroskop sederhana untuk melatihkan keterampilan proses sains dan pemahaman konsep materi Sistem Organisasi Kehidupan.

Subjek penelitian ini adalah perangkat pembelajaran. Uji coba dilakukan di SMP Negeri 2 Losari Kabupaten Brebes Provinsi Jawa Tengah kelas VII 2016/2017. Penelitian dilaksanakan dalam 2 Tahap. Tahap pengembangan di Unesa, Februari sampai Juli 2016. Tahap Uji Coba Uji Coba I Agustus 2016 dengan sampel 12 siswa dan Uji Coba 2 Oktober 2016 dengan populasi 30 siswa

Tahap penelitian meliputi 2 tahap yakni Penelitian tahap perancangan perangkat pembelajaran dan tahap uji coba perangkat. Model yang digunakan dalam pengembangan perangkat adalah Model 4-D (Thiagarajan, Semmel, dan Semmel: 1974) sedangkan 
untuk pemilihan media menggunakan model ASSURE (Smaldino, et al., 2011).

Rancangan penelitian ini menggunakan one group pretest-posttest design. Teknik pengumpulan data yang digunakan dalam penelitian ini adalah pengamatan, tes, dan angket respon siswa. Instrumen yang dikembangkan oleh peneliti berupa lembar validasi perangkat, lembar pengamatan keterlaksanaan RPP, lembar pengamatan aktivitas siswa, lembar penilaian keterampilan proses sains, lembar penilaian pemahaman konsep, dan lembar angket respon siswa. Teknik analisis data yang digunakan peneliti dalam penelitian ini adalah analisis deskriptif.

\section{HASIL PENELITIAN DAN DISKUSI}

Hasil penelitian ini ada tiga, yaitu: validitas perangkat pembelajaran, kepraktisan perangkat pembelajaran yang ditunjukkan oleh keterlaksanaan RPP, aktivitas siswa dan keefektifan perangkat pembelajaran yang ditunjukkan oleh hasil belajar siswa dan respon siswa. Uraian lengkapnya adalah sebagai berikut:

\section{A. Validitas Perangkat Pembelajaran}

Tabel 1. Hasil Validasi Perangkat oleh 2 Validator Ahli

\begin{tabular}{|l|c|c|}
\hline \multirow{2}{*}{ Perangkat Pembelajaran } & \multicolumn{2}{|c|}{ Hasil Validasi } \\
\cline { 2 - 3 } & Rata-rata & Kategori \\
\hline Silabus & 3,50 & Valid \\
\hline RPP & 3,54 & Sangat Valid \\
\hline LKS & 3,65 & Sangat Valid \\
\hline Buku Ajar Siswa & 3,55 & Sangat Valid \\
\hline $\begin{array}{l}\text { Media Mikroskop } \\
\text { Sederhana }\end{array}$ & 3,57 & Sangat Valid \\
\hline $\begin{array}{l}\text { Instrumen tes } \\
\text { Keterampilan Proses } \\
\text { Sains }\end{array}$ & 3,67 & Sangat Valid \\
\hline $\begin{array}{l}\text { Instrumen tes } \\
\text { Pemahaman Konsep }\end{array}$ & 3,83 & Sangat Valid \\
\hline
\end{tabular}

Tabel 1. menunjukkan bahwa hasil pengembangan perangkat pembelajaran yang dikembangkan oleh peneliti layak untuk digunakan dalam pembelajaran. Kelayakan perangkat pembelajaran dapat dilihat berdasarkan hasil validitas perangkat yang mendapat kategori minimal valid.

Media mikroskop sederhana yang dikembangkan memiliki kelebihan dan kekurangan. Kelebihan mikroskop sederhana antara lain terbuat dari bahan yang mudah diperoleh dari lingkungan sekitar, proses pembuatannya tidak sulit sehingga siswa membuatnya sendiri. Kekurangan mikroskop sederhana adalah hanya mampu melihat obyek dengan perbesaran 20 kali dari ukuran sebenarnya, sehingga untuk melihat sel yang ukurannya terlampau kecil tidak begitu jelas hanya bisa Pengembangan Perangkat Pembelajaran Penemuan Terbimbing Berbantuan Mikroskop Sederhana ........... melihat ukuran sel yang besar seperti sel umbi bawang merah dan ukuran tingkat jaringan.

Mikroskop sederhana ini memberi sumbangan riil pada pembelajaran IPA terutama pada materi sistem organisasi kehidupan. Namun tidak menutup kemungkinan pada materi IPA yang lain, seperti materi klasifikasi makhluk hidup. Walaupun tergolong sederhana media mikroskop sederhana dapat menjadi solusi alternative bagi sekolah yang belum tersedia mikroskop cahaya konvensional (Model student).

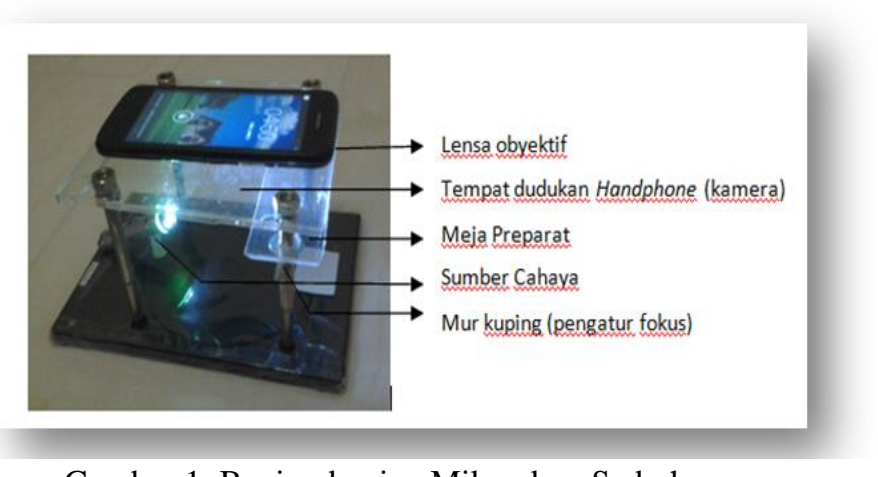

Gambar 1. Bagian-bagian Mikroskop Sederhana (Dokumen pribadi)

\section{B. Kepraktisan perangkat pembelajaran}

1) Keterlaksanaan RPP

Kegiatan pembelajaran dilaksanakan selama 3 kali pertemuan dengan alokasi waktu masing-masing pertemuan pertama 2 x 40 menit, pertemuan kedua $3 \mathrm{x}$ 40 menit, dan pertemuan ketiga 2 x 40 menit.

Tabel 2. Keterlaksanaan RPP

\begin{tabular}{|l|c|}
\hline Pertemuan & Persentase \\
\hline Pertemuan I & $100 \%$ \\
\hline Pertemuan II & $100 \%$ \\
\hline Pertemuan III & $100 \%$ \\
\hline
\end{tabular}

Tabel 3. Rata-Rata Skor Keterlaksanaan RPP

\begin{tabular}{|l|c|}
\hline Tahap Kegiatan & Rata-rata Skor \\
\hline Pendahuluan & 3,9 \\
\hline Inti & 3,9 \\
\hline Penutup & 3,9 \\
\hline Suasana Kelas & 3,8 \\
\hline Pengelolaan Waktu & 3,8 \\
\hline
\end{tabular}

Hasil pengamatan keterlaksanaan pembelajaran Tabel 2 dapat diketahui bahwa keterlaksanaan tahapan pembelajaran pada pertemuan pertama, pertemuan kedua dan pertemuan ketiga mencapai $100 \%$ dengan kategori terlaksana baik. 
Tahap kegiatan pendahuluan. Berdasarkan Tabel 3 diketahui rata-rata skor seluruh aspek kegiatan pendahuluan dari ketiga pertemuan sebesar 3,9 dengan kategori baik (Ratumanan dan Laurens, 2011). Percentage of Agreement sebesar 99\% dengan kategori cocok (Borich, 1994). Hal ini berarti tahapan pendahuluan menurut dua pengamat telah terlaksana dengan baik. Hasil yang mendukung perolehan nilai baik menurut kedua pengamat, karena peneliti meyakini bahwa guru telah melakukan tahapan pada kegiatan pendahuluan dengan baik. Kegiatan yang dilakukan guru antara lain memberi salam dan mengecek kehadiran siswa, memberi motivasi siswa, menyampaikan tujuan pembelajaran dan orientasi masalah. Kegiatan pendahuluan yang baik merupakan awal yang baik dan dapat meningkatkan rasa ingin tahu siswa sehingga siswa lebih antusias untuk mengikuti pelajaran selanjutnya.

Tahap kegiatan inti. Berdasarkan Tabel 3, rata-rata skor seluruh aspek kegiatan inti dari ketiga pertemuan sebesar 3,9 dengan kategori baik (Ratumanan dan Laurens, 2011). Percentage of Agreement sebesar 98,9\% dengan kategori cocok (Borich, 1994). Hal ini berarti tahapan kegiatan inti menurut dua pengamat adalah baik. Hasil yang mendukung perolehan nilai baik menurut kedua pengamat, karena peneliti meyakini bahwa guru telah melakukan tahapan pada kegiatan inti dengan baik. Kegiatan pada tahap ini meliputi: mengorganisasi siswa dalam belajar, membimbing siswa dalam penyelidikan, membantu siswa menginterprestasi data, membantu menyajikan atau mempresentasikan hasil penyelidikan. Siswa diorganisasi dalam bentuk 6 kelompok, masingmasing kelompok terdiri atas 5 siswa Setiap kelompok akan dibekali Buku Ajar Siswa (BAS), Lembar Kegiatan Siswa (LKS), dan seperangkat alat serta bahan penyelidikan untuk melaksanakan tugas penyelidikan yang ada dipetunjuk LKS. Setelah diorganisasi dalam kelompok, masing-masing kelompok melakukan penyelidikan/ pengamatan menggunakan mikroskop sederhana. Bimbingan guru dalam melakukan pengamatan sangat diperlukan.

Pertemuan pertama, siswa masih kesulitan membuat sayatan preparat bawang merah setipis mungkin, sehingga mereka berulang-ulang memperbaiki preparat bawang merah. Selain itu keterampilan siswa menggunakan mikroskop sederhana masih rendah, guru senantiasa mendampingi dan membimbing dalam menggunakan mikroskop sederhana. Setelah memperoleh hasil pengamatan siswa juga masih bingung dengan apa yang harus mereka gambarkan pada lembar LKS, bagian mana yang harus mereka gambar dan bagaimana cara mengidentifikasi ciri atau karakteristik obyek yang

Pengembangan Perangkat Pembelajaran Penemuan Terbimbing Berbantuan Mikroskop Sederhana ........... diamati. Pada pertemuan kedua siswa sudah bisa membuat preparat setipis mungkin, bisa menggunakan mikroskop sederhana. Bimbingan guru pada pertemuan kedua frekuensinya mulai berkurang, siswa yang telah mampu melakukan pengamatan memberi tahu kepada siswa yang belum tahu atau belum bisa. Pada pertemuan ketiga siswa sudah terbiasa dengan kegiatan pengamatan. Setelah melakukan pengamatan, masing-masing kelompok menuliskan hasil pengamatan, menginterprestasikan data, dan mendiskusikan dalam kelompoknya. Kegiatan berikutnya adalah mempresentasikan hasil diskusi kelompoknya secara klasikal. Peran guru disini memberi konfirmasi, penguatan dan umpan balik proses pembelajaran.

Tahap kegiatan penutup. Berdasarkan Tabel 3, ratarata skor seluruh aspek kegiatan penutup dari ketiga pertemuan sebesar 3,9 dengan kategori baik (Ratumanan dan Laurens, 2011). Percentage of Agreement sebesar 96,4\% dengan kategori cocok (Borich, 1994). Hal ini berarti tahapan penutup menurut dua pengamat adalah baik. Hasil yang mendukung perolehan nilai baik menurut kedua pengamat, karena peneliti meyakini bahwa guru telah melakukan tahapan pada kegiatan penutup dengan baik. Kegiatan penutup yang dilakukan guru bersama siswa menyimpulkan hasil pembelajaran. Selanjutnya guru memberi kesempatan bertanya pada siswa bilamana dalam benaknya masih ada materi yang belum dimengerti. Kegiatan terakhir guru memberikan tugas rumah untuk mempelajari materi yang akan di bahas dipertemuan berikutnya.

Aspek suasana kelas dari ketiga pertemuan memperoleh skor rata-rata sebesar 3,8 dengan kategori baik (Ratumanan dan Laurens, 2011). Percentage of Agreement sebesar 95,2\% dengan kategori cocok (Borich, 1994). Hal ini berarti aspek suasana kelas menurut dua pengamat adalah baik. Hasil yang mendukung perolehan nilai baik menurut kedua pengamat, karena peneliti meyakini bahwa guru telah melakukan manajemen pembelajaran dengan baik sehingga suasana kelas dengan baik. Semangat guru untuk memberikan pembelajaran menggunakan model pembelajaran penemuan terbimbing berbantuan mikroskop sederhana tinggi, guru selalu membimbing siswa dalam melakukan pengamatan, guru mengingatkan siswa jika ada siswa yang bertindak tidak relevan. Siswa antusias untuk melaksanakan kegiatan pengamatan menggunakan mikroskop sederhana, membaca buku, berdiskusi. Siswa tidak malu untuk bertanya pada guru atau teman bila kesulitan untuk melakukan pengamatan. Selain itu tahapan penemuan terbimbing terlaksana dengan baik. 
Aspek pengelolaan waktu ketiga pertemuan memperoleh skor rata-rata sebesar 3,8 dengan kategori baik (Ratumanan dan Laurens, 2011). Percentage of Agreement sebesar 100\% dengan kategori cocok (Borich, 1994). Hal ini berarti aspek pengelolaan waktu menurut dua pengamat adalah baik. Hasil yang mendukung perolehan nilai baik menurut kedua pengamat, karena guru telah melakukan pengelolaan waktu dengan baik.

Keseluruhan aspek dalam keterlaksanaan pembelajaran dalam kategori baik, hal ini diyakini karena peneliti sudah semaksimal mungkin melaksanakan seluruh tahapan atau fase dalam pembelajaran sesuai dengan Rencana Pelaksanaan Pembelajaran. Pendapat Nur dalam Citrasukmawati (2012) bahwa salah satu faktor yang mempengaruhi kualitas pembelajaran adalah tersedianya perangkat pembelajaran yang disertai dengan komitmen yang tinggi untuk menggunakannya dalam setiap pembelajaran.

\section{2) Aktivitas Siswa}

Aktivitas siswa merupakan kegiatan yang dilakukan siswa selama proses pembelajaran berlangsung. Dalam penelitian ini terdapat 11 aktivitas yang diamati. Berikut adalah gambar grafik aktivitas siswa selama 3 kali pertemuan.

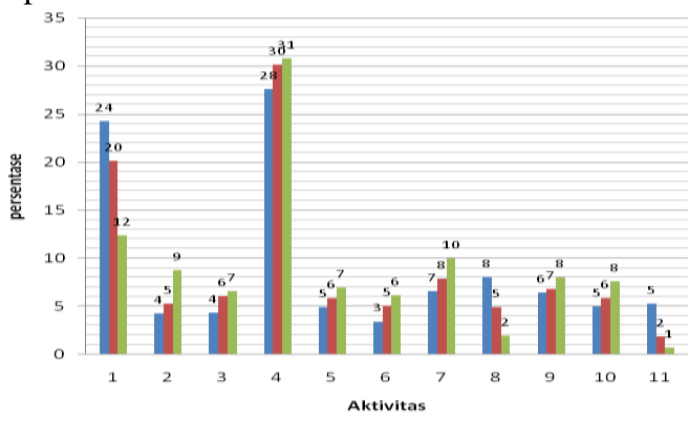

- Pertemuan - Pertemuan 2 = Pertemuan 3

Gambar 2. Grafik Hasil Pengamatan Aktivitas Siswa selama KBM Pembelajaran Penemuan Terbimbing Berbantuan Mikroskop Sederhana

Keterangan :

Aktivitas :

1. Memperhatikan penjelasan guru

2. Mengamati fenomena

3. Menanya

4. Melakukan kegiatan penyelidikan/ pengamatan menggunakan mikroskop sederhana

5. Menuliskan hasil pengamatan

6. Menginterprestasi data

7. Membaca buku ajar

8. Meminta bimbingan guru

9. Mengomunikasikan hasil penyelidikan

10. Membuat kesimpulan

11. Aktivitas tidak relevan
Berdasarkan Gambar 2 diketahui bahwa aktivitas yang dominan pada tiap pertemuan adalah aktivitas melakukan pengamatan/penyelidikan menggunakan mikroskop sederhana dan alat serta bahan lain sesuai petunjuk LKS. Aktivitas ini mengalami peningkatan dari pertemuan pertama ke pertemuan kedua, pertemuan kedua ke pertemuan ketiga. Hasil tersebut terjadi karena masing-masing siswa antusias dan berusaha untuk melakukan pengamatan. Setiap siswa menginginkan memiliki pengalaman secara langsung mengamati obyek sesuai LKS menggunakan Mikroskop Sederhana. Pada pertemuan ketiga siswa sangat antusias karena obyek yang diamati terlihat hidup dan bergerak, yaitu mengamati Daphnia Sp.. Melalui pengalaman langsung, keterampilan proses sain siswa terutama keterampilan menggunakan alat dan keterampilan mengamati akan terlatih serta pemahaman konsep mengenai materi siswa akan meningkat. Sesuai dengan teori penemuan Bruner bahwa siswa menggunakan pengalaman atau pengamatan langsung untuk mendapatkan informasi dan teori kerucut pengalaman Dale yang menyatakan pengalaman langsung akan memberi kesan paling bermakna dan penyimpanan paling lama.

Berdasarkan hasil analisis membuktikan bahwa aktivitas siswa secara umum mengalami peningkatan dalam di setiap pertemuan. Hal ini sejalan dengan hasil penelitian Allo (2015) bahwa model pembelajaran Guided Discovery memberikan pengalaman lebih bagi siswa dalam belajar. Suryani (2016) juga menambahkan pembelajaran model Guided Discovery menjadikan siswa semakin berpartisipasi dengan baik. Senada dengan penelitian di atas Hermawan dan Sondang (2013) dalam penelitiannya mengungkapkan bahwa aktivitas siswa kelas yang menggunakan model Guided Discovery lebih baik daripada kelas konvensional. Oyolede (2010) mempertegas bahwa melalui Guided Discovery, siswa berpartisipasi aktif selama proses belajar mengajar.

\section{Keefektivan Perangkat Pembelajaran \\ 1. Keterampilan Proses Sains}

Penilaian keterampilan proses sains didasarkan pada tes yang dilakukan sebelum (pretest) dan sesudah (posttest) pembelajaran.

Tabel 4. Ketuntasan Individual dan klasikal Keterampilan Proses

\begin{tabular}{|c|c|c|c|c|c|c|}
\hline \multirow{2}{*}{ No } & \multirow{2}{*}{$\begin{array}{c}\text { Inisial } \\
\text { Siswa }\end{array}$} & \multicolumn{2}{|c|}{ Pretest } & \multicolumn{2}{|c|}{ Posttest } & \multirow{2}{*}{ Ketuntasan } \\
\cline { 3 - 6 } & Skor & Nilai & Skor & Nilai & \\
\hline 1 & A01 & 14 & 1,87 & 29 & 3,87 & T \\
\hline 2 & A02 & 12 & 1,60 & 19 & 2,53 & TT \\
\hline 3 & A03 & 14 & 1,87 & 26 & 3,47 & T \\
\hline
\end{tabular}




\begin{tabular}{|c|c|c|c|c|c|c|}
\hline \multirow{2}{*}{ No } & \multirow{2}{*}{$\begin{array}{l}\text { Inisial } \\
\text { Siswa }\end{array}$} & \multicolumn{2}{|c|}{ Pretest } & \multicolumn{2}{|c|}{ Posttest } & \multirow{2}{*}{ Ketuntasan } \\
\hline & & Skor & Nilai & Skor & Nilai & \\
\hline 4 & A04 & 13 & 1,73 & 25 & 3,33 & $\mathrm{~T}$ \\
\hline 5 & A05 & 14 & 1,87 & 22 & 2,93 & $\mathrm{~T}$ \\
\hline 6 & A06 & 14 & 1,87 & 22 & 2,93 & $\mathrm{~T}$ \\
\hline 7 & A07 & 13 & 1,73 & 23 & 3,07 & $\mathrm{~T}$ \\
\hline 8 & A08 & 17 & 2,27 & 23 & 3,07 & $\mathrm{~T}$ \\
\hline 9 & A09 & 10 & 1,33 & 19 & 2,53 & TT \\
\hline 10 & A10 & 14 & 1,87 & 26 & 3,47 & $\mathrm{~T}$ \\
\hline 11 & A11 & 15 & 2,00 & 25 & 3,33 & $\mathrm{~T}$ \\
\hline 12 & A12 & 11 & 1,47 & 27 & 3,60 & $\mathrm{~T}$ \\
\hline 13 & A13 & 12 & 1,60 & 23 & 3,07 & $\mathrm{~T}$ \\
\hline 14 & A14 & 14 & 1,87 & 25 & 3,33 & $\mathrm{~T}$ \\
\hline 15 & A15 & 14 & 1,87 & 27 & 3,60 & $\mathrm{~T}$ \\
\hline 16 & A16 & 13 & 1,73 & 25 & 3,33 & $\mathrm{~T}$ \\
\hline 17 & A17 & 13 & 1,73 & 25 & 3,33 & $\mathrm{~T}$ \\
\hline 18 & A18 & 10 & 1,33 & 26 & 3,47 & $\mathrm{~T}$ \\
\hline 19 & A19 & 13 & 1,73 & 23 & 3,07 & $\mathrm{~T}$ \\
\hline 20 & A20 & 17 & 2,27 & 25 & 3,33 & $\mathrm{~T}$ \\
\hline 21 & A21 & 12 & 1,60 & 24 & 3,20 & $\mathrm{~T}$ \\
\hline 22 & A22 & 19 & 2,53 & 30 & 4,00 & $\mathrm{~T}$ \\
\hline 23 & A23 & 12 & 1,60 & 24 & 3,20 & $\mathrm{~T}$ \\
\hline 24 & A24 & 16 & 2,13 & 25 & 3,33 & $\mathrm{~T}$ \\
\hline 25 & A25 & 10 & 1,33 & 25 & 3,33 & $\mathrm{~T}$ \\
\hline 26 & A26 & 13 & 1,73 & 25 & 3,33 & $\mathrm{~T}$ \\
\hline 27 & A27 & 13 & 1,73 & 28 & 3,73 & $\mathrm{~T}$ \\
\hline 28 & A28 & 12 & 1,60 & 26 & 3,47 & $\mathrm{~T}$ \\
\hline 29 & A29 & 10 & 1,33 & 19 & 2,53 & $\mathrm{TT}$ \\
\hline 30 & A30 & 14 & 1,87 & 26 & 3,47 & $\mathrm{~T}$ \\
\hline
\end{tabular}

Keterangan:

$\mathrm{T}:$ Tuntas TT $:$ Tidak Tuntas

Tabel 5. Hasil Pengelompokan Keterampilan Proses Sains Pada Uji Coba 2

\begin{tabular}{|c|c|c|c|c|c|c|c|c|c|c|c|c|c|c|}
\hline \multirow{3}{*}{$\begin{array}{c}\text { Jumlah } \\
\text { siswa }\end{array}$} & \multicolumn{6}{|c|}{ Pretest } & \multirow{3}{*}{ Total } & \multicolumn{6}{|c|}{ Postest } & \multirow{3}{*}{ Total } \\
\hline & \multicolumn{3}{|c|}{ Kategori } & \multicolumn{3}{|c|}{ (\%) } & & \multicolumn{3}{|c|}{ Kategori } & \multicolumn{3}{|c|}{$(\%)$} & \\
\hline & R & $s$ & $\mathrm{~T}$ & $\mathbf{R}$ & $\mathbf{S}$ & $\mathbf{T}$ & & $\mathbf{R}$ & $\mathbf{s}$ & $\mathrm{T}$ & R & $\mathbf{s}$ & $\mathrm{T}$ & \\
\hline 30 & 4 & 26 & 0 & 13 & 87 & 0 & 100 & 0 & 3 & 27 & 0 & 10 & 90 & 100 \\
\hline
\end{tabular}

Pengembangan Perangkat Pembelajaran Penemuan Terbimbing Berbantuan Mikroskop Sederhana ...........
Berdasarkan Tabel 4. diketahui keterampilan proses sains yang diperoleh siswa sebelum diberi perlakuan seluruh siswa belum tuntas. Hasil ini dikarenakan siswa belum terlatih dengan proses sains, materi yang ditanyakan belum pernah diajarkan, penggunakan mikroskop sederhana belum pernah dilatihkan hanya sebatas pengenalan saja komponen dan cara menggunakan. Setelah diberi pembelajaran penemuan terbimbing berbantuan mikroskop sederhana selama tiga kali pertemuan, ada tiga siswa (A02, A09 dan A029) masih tidak tuntas. Hal ini disebabkan siswa tidak aktif dalam melakukan pengamatan, membaca buku ajar, dan berpartisipasi dalam diskusi. Siswa yang tidak tuntas diberikan remedial, untuk menuntaskan keterampilan proses mereka dengan diberi tes.

Berdasarkan Tabel 5 diketahui pada pretest siswa yang masuk kategori keterampilan proses rendah $13 \%$, sedang $87 \%$ dan tinggi $0 \%$. Sedangkan pada posttest siswa yang masuk kategori keterampilan proses rendah 0\%, sedang $10 \%$ dan tinggi $90 \%$.

Tabel 6. Ketuntasan Indikator Keterampilan Proses

\begin{tabular}{|c|c|c|c|c|c|c|c|}
\hline \multirow[b]{2}{*}{ No } & \multirow[b]{2}{*}{ Indikator/ Aspek } & \multicolumn{2}{|c|}{ Jumlah skor } & \multicolumn{2}{|l|}{ Pretest } & \multicolumn{2}{|l|}{ Posttest } \\
\hline & & Pretest & Posttest & $\begin{array}{c}\text { Ketuntasan } \\
(\%)\end{array}$ & $\mathrm{K}$ & $\begin{array}{c}\text { Ketuntasan } \\
(\%)\end{array}$ & $\mathrm{K}$ \\
\hline 1 & $\begin{array}{l}\text { Keterampilan } \\
\text { mengamati }\end{array}$ & 60 & 106 & 50,0 & $\mathrm{TT}$ & 88,3 & $\mathrm{~T}$ \\
\hline 2 & Keterampilan menanya & 71 & 111 & 59,2 & $\mathrm{TT}$ & 92,5 & $\mathrm{~T}$ \\
\hline 3 & $\begin{array}{l}\text { Keterampilan } \\
\text { menggunakan } \\
\text { mikroskop dan alat serta } \\
\text { bahan lain melakukan } \\
\text { pengamatan/ } \\
\text { penyelidikan }\end{array}$ & 88 & 182 & 36,7 & TT & 75,8 & $\mathrm{~T}$ \\
\hline 4 & $\begin{array}{l}\text { Keterampilan } \\
\text { menginterprestasi data }\end{array}$ & 59 & 113 & 39,3 & TT & 75,3 & $\mathrm{~T}$ \\
\hline 5 & $\begin{array}{l}\text { Keterampilan } \\
\text { mengkomunikasikan }\end{array}$ & 64 & 120 & 42,7 & TT & 80,0 & $\mathrm{~T}$ \\
\hline 6 & $\begin{array}{l}\text { keterampilan } \\
\text { menyimpulkan }\end{array}$ & 56 & 105 & 46,7 & TT & 87,5 & $\mathrm{~T}$ \\
\hline
\end{tabular}

Berdasarkan Tabel 6. dapat diketahui bahwa seluruh indikator keterampilan proses pada posttest (setelah pembelajaran) dalam kategori tuntas, hal ini berarti penerapan model penemuan terbimbing berbantuan mikroskop sederhana dapat menuntaskan keterampilan proses sains. Indikator yang paling kecil persentasenya adalah menggunakan alat/ bahan untuk memperoleh data dan menginter-prestasikan data. Hasil ini diperoleh karena siswa masih kesulitan dalam mencari fokus bayangan yang dihasilkan sehingga dalam menginterprestasikan data berupa gambar siswa juga masih merasa kesulitan.

Hal yang mendukung ketercapaian hasil tes keterampilan proses sains yang lebih baik adalah keterampilan proses sains diberikan dan dilatihkan selama tiga kali pertemuan. Pada pertemuan pertama guru memodelkan terlebih dahulu cara melakukan pengamatan, bagaimana cara menggunakan mikroskop 
sederhana walaupun pada saat kegiatan pengenalan sudah dilaksanakan. Selanjutnya masing-masing siswa diminta untuk mencoba melakukan sendiri dalam kelompoknya. Pada pertemuan kedua, siswa tidak lagi diberi contoh tetapi siswa langsung bekerja sesuai petunjuk LKS, guru hanya membimbing jika siswa mengalami kesulitan dan memfasilitasi kegiatan penyelidikan/ pengamatan. Pertemuan ketiga siswa telah terbiasa dengan aktivitas mengamati. Sehingga keterampilan siswa terlatihkan dari pertemuan pertama, kedua, hingga ketiga. Dahar (1988) menambahkan siswa mulai terbiasa dengan setiap aktivitas pembelajaran yang dilakukan dengan melakukan beberapa kali pengulangan dalam pembelajaran. Adanya perangkat RPP pembelajaran penemuan terbimbing menjadikan pencapaian nilai keterampilan proses siswa juga meningkat, karena dalam RPP tersebut menuntun guru mengelola pembelajaran untuk siswa melakukan proses sains baik mengamati, menanya, menggunakan alat/bahan, menginterprestasi data, mengkomunikasikan dan menyimpulkan. Faktor lain yang mendukung keterampilan proses sains siswa meningkat adalah keterlibatan aktif dalam pembelajaran setiap pertemuan. Selain itu bimbingan guru juga berpengaruh pada perolehan nilai posttest keterampilan proses sains walaupun aktivitas siswa meminta bimbingan guru dari pertemuan pertama ke pertemuan kedua dan pertemuan ke tiga mengalami penurunan. Faktor belajar dari teman sekelompok/ teman sebaya yang sudah mampu juga berpengaruh pada keterampilan proses sains beberapa siswa tidak enggan untuk bertanya kepada teman yang sudah mampu/pintar. Sesuai dengan Vigotsky bahwa pengajaran pribadi oleh teman sebaya yang lebih kompeten dapat berjalan efektif meningkatkan pertumbuhan pada zona perkembangan proksimal, demikian pula interaksi di sekitar tugas-tugas yang rumit (Slavin, 1994).

Tabel 7. N-Gain (Skor Peningkatan) Tes Keterampilan Proses

\begin{tabular}{|c|c|c|c|c|c|}
\hline \multirow{2}{*}{ No } & \multirow{2}{*}{$\begin{array}{c}\text { Inisial } \\
\text { Siswa }\end{array}$} & \multicolumn{2}{|c|}{ Skor } & \multirow{2}{*}{ Gain } & Keterangan \\
\cline { 3 - 5 } & Pretest & Postest & Score & \\
\hline 1 & A01 & 14 & 29 & 0,9 & Tinggi \\
\hline 2 & A02 & 12 & 19 & 0,4 & Sedang \\
\hline 3 & A03 & 14 & 26 & 0,8 & Tinggi \\
\hline 4 & A04 & 13 & 25 & 0,7 & Tinggi \\
\hline 5 & A05 & 14 & 22 & 0,5 & Sedang \\
\hline 6 & A06 & 14 & 22 & 0,5 & Sedang \\
\hline 7 & A07 & 13 & 23 & 0,6 & Sedang \\
\hline 8 & A08 & 17 & 23 & 0,5 & Sedang \\
\hline
\end{tabular}

Pengembangan Perangkat Pembelajaran Penemuan Terbimbing Berbantuan Mikroskop Sederhana ...........

\begin{tabular}{|c|c|c|c|c|c|}
\hline \multirow{2}{*}{ No } & \multirow{2}{*}{$\begin{array}{c}\text { Snisial } \\
\text { Siswa }\end{array}$} & \multicolumn{2}{|c|}{ Skor } & Gain & Keterangan \\
\cline { 3 - 4 } & Pretest & Postest & Score & \\
\hline 9 & A09 & 10 & 19 & 0,5 & Sedang \\
\hline 10 & A10 & 14 & 26 & 0,8 & Tinggi \\
\hline 11 & A11 & 15 & 25 & 0,7 & Sedang \\
\hline 12 & A12 & 11 & 27 & 0,8 & Tinggi \\
\hline 13 & A13 & 12 & 23 & 0,6 & Sedang \\
\hline 14 & A14 & 14 & 25 & 0,7 & Sedang \\
\hline 15 & A15 & 14 & 27 & 0,8 & Tinggi \\
\hline 16 & A16 & 13 & 25 & 0,7 & Tinggi \\
\hline 17 & A17 & 13 & 25 & 0,7 & Tinggi \\
\hline 18 & A18 & 10 & 26 & 0,8 & Tinggi \\
\hline 19 & A19 & 13 & 23 & 0,6 & Sedang \\
\hline 20 & A20 & 17 & 25 & 0,6 & Sedang \\
\hline 21 & A21 & 12 & 24 & 0,7 & Sedang \\
\hline 22 & A22 & 19 & 30 & 1,0 & Tinggi \\
\hline 23 & A23 & 12 & 24 & 0,7 & Sedang \\
\hline 24 & A24 & 16 & 25 & 0,6 & Sedang \\
\hline 25 & A25 & 10 & 25 & 0,8 & Tinggi \\
\hline 26 & A26 & 13 & 25 & 0,7 & Tinggi \\
\hline 27 & A27 & 13 & 28 & 0,9 & Tinggi \\
\hline 28 & A28 & 12 & 26 & 0,8 & Tinggi \\
\hline 29 & A29 & 10 & 19 & 0,5 & Sedang \\
\hline 30 & A30 & 14 & 26 & 0,8 & Tinggi \\
\hline & & & & & \\
\hline 12 & & & & \\
\hline
\end{tabular}

Berdasarkan Tabel 7, keterampilan proses sains sangat rendah ditunjukkan nilai pretest siswa rendah atau tidak tuntas. Hal ini disebabkan karena siswa belum pernah menerima materi yang diujikan, sehingga siswa mengalami kesulitan ketika mengerjakan soal. Waktu yang digunakan untuk pengenalan terhadap mikroskop sederhanapun tidak banyak, jadi siswa masih belum begitu paham bagaimana cara mengoperasikannya. Pada posttest, keterampilan proses sains meningkat, hal ini dibuktikan dari hasil perhitungan $N$-Gain tes keterampilan proses sains siswa dalam kategori sedang.

Hal yang mendukung ketercapaian hasil tes keterampilan proses sains yang lebih baik adalah keterampilan proses sains diberikan dan dilatihkan selama tiga kali pertemuan. Pada pertemuan pertama guru memodelkan terlebih dahulu cara melakukan pengamatan, bagaimana cara menggunakan mikroskop sederhana walaupun pada saat kegiatan pengenalan sudah 
dilaksanakan. Selanjutnya masing-masing siswa diminta untuk mencoba melakukan sendiri dalam kelompoknya. Pada pertemuan kedua, siswa tidak lagi diberi contoh tetapi siswa langsung bekerja sesuai petunjuk LKS, guru hanya membimbing jika siswa mengalami kesulitan dan memfasilitasi kegiatan penyelidikan/ pengamatan. Pertemuan ketiga siswa telah terbiasa dengan aktivitas mengamati. Sehingga keterampilan siswa terlatihkan dari pertemuan pertama, kedua, hingga ketiga. Dahar (1988) menambahkan siswa mulai terbiasa dengan setiap aktivitas pembelajaran yang dilakukan dengan melakukan beberapa kali pengulangan dalam pembelajaran. Adanya perangkat RPP pembelajaran penemuan terbimbing menjadikan pencapaian nilai keterampilan proses siswa juga meningkat, karena dalam RPP tersebut menuntun guru mengelola pembelajaran untuk siswa melakukan proses sains baik mengamati, menanya, menggunakan alat/bahan, menginterprestasi data, mengkomunikasikan dan menyimpulkan. Faktor lain yang mendukung keterampilan proses sains siswa meningkat adalah keterlibatan aktif dalam pembelajaran setiap pertemuan. Selain itu bimbingan guru juga berpengaruh pada perolehan nilai posttest keterampilan proses sains walaupun aktivitas siswa meminta bimbingan guru dari pertemuan pertama ke pertemuan kedua dan pertemuan ke tiga mengalami penurunan. Faktor belajar dari teman sekelompok/ teman sebaya yang sudah mampu juga berpengaruh pada keterampilan proses sains beberapa siswa tidak enggan untuk bertanya kepada teman yang sudah mampu/pintar. Sesuai dengan Vigotsky bahwa pengajaran pribadi oleh teman sebaya yang lebih kompeten dapat berjalan efektif meningkatkan pertumbuhan pada zona perkembangan proksimal, demikian pula interaksi di sekitar tugas-tugas yang rumit (Slavin, 1994).

Dari uraian di atas dapat diringkas bahwa setelah menggunakan model penemuan terbimbing berbantuan mikroskop sederhana keterampilan proses sains siswa lebih meningkat dan memiliki keterampilan proses sains dengan kategori tinggi. Hal ini sejalan dengan hasil penelitian yang dilakukan oleh Suryani (2016) bahwa Model Guided Discovery memberikan hasil positif terhadap keterampilan proses sains pada siswa SMP. Sari (2014) dalam penelitiannya juga menambahkan bahwa keterampilan mengamati siswa berbantuan media animasi mengalami peningkatan dari pertemuan pertama ke pertemuan kedua dan pertemuan ketiga. Arjunan \& Jayachandran (2012) memperkuat bahwa retensi keterampilan psikomotor yang diperoleh dengan gaya mengajar menggunakan penemuan terbimbing lebih

Pengembangan Perangkat Pembelajaran Penemuan Terbimbing Berbantuan Mikroskop Sederhana ........... unggul dibandingkan dengan pengajaran yang menggunakan perintah dan berpusat pada guru.

\section{Pemahaman Konsep}

Pemahaman konsep siswa dapat diketahui melalui pemberian tes. Tes dilakukan 2 kali yaitu pretest dan posttest.

Tabel 8. Hasil Analisis Ketuntasan Indikator Pemahaman Konsep

\begin{tabular}{|c|c|c|c|c|c|c|c|}
\hline \multirow{4}{*}{ No } & \multirow{4}{*}{$\begin{array}{l}\text { Indikator } \\
\text { Pemahaman } \\
\text { Konsep }\end{array}$} & \multirow{2}{*}{\multicolumn{2}{|c|}{$\begin{array}{c}\text { Jumlah } \\
\text { Jawaban }\end{array}$}} & \multicolumn{2}{|l|}{ Pretest } & \multicolumn{2}{|l|}{ Posttest } \\
\hline & & & & \multirow{3}{*}{$\begin{array}{c}\text { Ketuntasan } \\
(\%)\end{array}$} & \multirow[t]{3}{*}{$\mathrm{K}$} & \multirow{3}{*}{$\begin{array}{c}\text { Ketuntasan } \\
(\%)\end{array}$} & \multirow[t]{3}{*}{ K } \\
\hline & & \multicolumn{2}{|c|}{ Benar } & & & & \\
\hline & & Pretest & Posttest & & & & \\
\hline 1 & Menjelaskan & 23 & 75 & 26 & TT & 81 & $\mathrm{~T}$ \\
\hline 2 & Membandingkan & 12 & 45 & 20 & TT & 75 & $\mathrm{~T}$ \\
\hline 3 & Mengklasifikasi & 15 & 46 & 25 & TT & 77 & $\mathrm{~T}$ \\
\hline 4 & Memberi contoh & 11 & 48 & 18 & TT & 80 & $\mathrm{~T}$ \\
\hline 5 & Meringkas & 14 & 46 & 23 & TT & 77 & $\mathrm{~T}$ \\
\hline 6 & Menafsirkan & 15 & 45 & 25 & TT & 75 & $\mathrm{~T}$ \\
\hline \multirow[t]{2}{*}{7} & Menarik inferensi & 13 & 45 & 22 & TT & 75 & $\mathrm{~T}$ \\
\hline & Rata-rata & & & 22,71 & TT & 77,14 & $\mathrm{~T}$ \\
\hline
\end{tabular}

Berdasarkan Tabel 8 diketahui indikator pemahaman konsep mencapai ketuntasan rata-rata sebesar 77, 14 dan dikategorikan tuntas.

Berdasarkan Tabel 8 dapat diketahui bahwa ketuntasan indikator pemahaman konsep setelah pembelajaran menggunakan perangkat penemuan terbimbing dalam kategori tuntas. Peningkatan skor pada tes pemahaman konsep pada uji coba II dengan kategori sedang. Artinya pemberian pembelajaran Model Penemuan Terbimbing Berbantuan Mikroskop Sederhana memberikan peningkatan terhadap pemahaman konsep siswa pada materi Sistem Organisasi Kehidupan. Hal-hal yang menunjang terjadinya peningkatan pemahaman konsep siswa antara lain keterlibatan siswa secara aktif selama proses pembelajaran, siswa aktif melakukan pengamatan, membaca buku ajar, berpartisipasi dalam diskusi. Melalui keaktivan siswa melakukan penyelidikan/ pengamatan menggunakan mikroskop sederhana, pemahaman siswa mengenai sel bagaimana bentuk sel sesungguhnya, bagian apa saja yang menyusun sel sesungguhnya dapat dimengerti dan dipahami siswa secara lebih mendalam dibenak mereka. Keterlibatan guru menciptakan suasana kelas yang baik juga turut serta menunjang peningkatan pemahaman konsep. Sejalan dengan Arends (2008) dalam Windarti (2013) yang menyatakan bahwa keterlibatan guru menciptakan kelas yang hangat dan penuh perhatian dengan banyaknya praktik (melakukan penyelidikan/ pengamatan) merupakan motivasi yang suportif, dan selalu menunjukkan perencanaan yang baik menghasilkan hasil kerja siswa mencapai tingkat yang tinggi. Buku Ajar Siswa juga memiliki peranan penting terhadap peningkatan pemahaman konsep siswa, kemudahan 
bahasa yang digunakan pada buku siswa dan penampilan yang menarik berkontribusi terhadap pemahaman konsep karena siswa mudah memahami materi yang disajikan. Hal ini menjadikan buku siswa efektif untuk memandu siswa belajar di kelas. Kegiatan pembelajaran yang dilakukan terlaksana sesuai dengan RPP yang dikembangkan. Siswa diberi kesempatan untuk menemukan sendiri konsep yang dipelajari melalui penyelidikan/pengamatan, sehingga mendekatkan siswa dengan sesuatu yang dapat dilihat secara nyata. Dengan demikian belajar siswa akan lebih bermakna sehingga dampak pada daya ingat dan pemahaman siswa terhadap konsep-konsep akan lebih baik.

\section{Respon Siswa}

Pemberian dan pengisian angket respon siswa kepada 30 siswa uji coba II dilakukan setelah serangkaian kegiatan pretest, kegiatan pembelajaran dan posttest dilaksanakan. $85 \%$ siswa merasa senang terhadap komponen bahan kajian, Buku Ajar Siswa (BAS), LKS, Media pembelajaran, dan cara guru mengajar. $84 \%$ siswa merasa baru terhadap bahan kajian, Buku Ajar Siswa (BAS), LKS, Media pembelajaran, dan cara guru mengajar. Respon positif siswa terhadap Buku Ajar Siswa (BAS) $87 \%$, terhadap LKS $87 \%$, terhadap media mikroskop sederhana $90 \%$, terhadap model penemuan terbimbing $87 \%$. Hal ini menunjukkan bahwa tahapan pembelajaran dengan metode penemuan terbimbing menarik bagi siswa. Senada dengan penelitian Malokawati et al (2015) bahwa siswa lebih tertarik menggunakan metode penemuan terbimbing dibandingkan metode ceramah. Respon siswa terhadap proses kegiatan belajar mengajar bahwa guru memberikan penjelasan mudah dimengerti sebesar 90\%, guru memberikan bimbingan pada saat kegiatan belajar mengajar sebesar $87 \%$. Siswa sangat memerlukan bimbingan guru untuk mengatasi kesulitan pembelajaran.

Respon siswa terhadap sistem penilaian sebanyak 83\% siswa merespon positif. Penilaian yang digunakan tidak hanya penilaian pengetahuan dan keterampilan saja, penilaian sikap spiritual dan sosial juga dinilai, apalagi mereka berkesempatan untuk menilai diri sendiri dan menilai teman. Respon siswa terhadap penerapan model Pembelajaran Penemuan Terbimbing Berbantuan Mikroskop Sederhana dalam proses pembelajaran pada materi lain $80 \%$.

Secara keseluruhan siswa memberikan respon positif terhadap pembelajaran, respon positif ini menunjukkan siswa antusias dengan pembelajaran yang disajikan. Hal ini dapat memotivasi siswa untuk meningkatkan perhatian dan membuat siswa terlibat aktif dalam pembelajaran yang menyenangkan dan bermakna (Nur dan Wikandari, 2000).

\section{PENUTUP}

\section{A. Simpulan}

Berdasarkan hasil penelitian dan diskusi dapat disimpulkan bahwa perangkat pembelajaran yang dikembangkan menggunakan Model Penemuan Terbimbing Berbantuan Mikroskop Sederhana dinyatakan layak karena valid, praktis dan efektif dalam melatihkan keterampilan proses sains dan pemahaman konsep siswa SMP Negeri 2 Losari pada Materi Sistem Organisasi Kehidupan.

\section{B. Saran}

Beberapa saran dapat dilakukan oleh peneliti berdasarkan penelitian yang telah dilakukan adalah sebagai berikut:

1. Persiapan dan pengelolaan waktu perlu diperhatikan, karena penerapan perangkat pembelajaran Model Penemuan Terbimbing Berbantuan Mikroskop Sederhana membutuhkan waktu yang lebih lama.

2. Keterampilan menggunakan mikroskop sederhana dan menginterprestasikan data perlu mendapat perhatian, karena berdampak pada keterampilan mengkomunikasikan dan membuat kesimpulan hasil pengamatan/ penyelidikan.

3. Perlu dilakukan penelitian lebih lanjut menggunakan penemuan terbimbing dengan melatihkan keterampilan proses sains lainnya.

\section{DAFTAR PUSTAKA}

Allo, A. Y.(2015). Pengembangan Perangkat Pembelajaran Fisika Model Guided Discovery Learning Menggunakan Alat Sederhana untuk Mereduksi Miskonsepsi Siswa pada Materi Fluida Statis. Jurnal Pendidikan Sains Pascasarjana UNESA. Vol 5. No 1. November 2015 p. $769-778$

Arjunan, R and Jayachandran, R.(2012). Effect of Command and Guided Discovery Teaching Styles on Retention of a Psikomotor Skill". IOSR Journal of Humanities and Social Science (JHSS)ISSN: 2279-0837, ISBN : 2279-0845. Volume 1, Issue 6 (Sep-Oct. 2012), p 27-32.www.iosrjournals.org. Diakses tanggal 30 Juni 2016

Borich, G. (1994). Observation Skill for Effective Teaching. New York: Mac Millan Publishing Company.

Citrasukmawati, A.(2012). Pengembangan Perangkat Pembelajaran IPA dengan Tampilan Macromedia Flash di SMP. Jurnal Pendidikan 
Sains Pascasarjana UNESA. Vol 1. No 2 November 2012 p. 94-99

Dahar, W.R. (1988). Teori-Teori Belajar. Jakarta: Departemen pendidikan dan Kebudayaan Direktorat Jenderal Pendidikan Tinggi Proyek pengembangan Lembaga Pendidikan Tenaga Kependidikan.

Depdiknas. (2008). Panduan Pengembangan Bahan Ajar. Jakarta : Depdinas.

Hermawan, E., \& Sondang, M.S. (2013). Perbedaan Hasil Belajar Menggunakan Model Guided Discovery Dengan Model Inquiry Pada Pelajaran Memahami Sifat Dasar Sinyal Audio Di Smk N 2 Surabaya. Jurnal Pendidikan Teknik Elektro Vol 2, No 1 p. 31-39 (2013). http://ejournal.unesa.ac.id/index.php/jurnalpendidikan-teknik-elektro/article/view/715.

Ibrahim, M. (2012). Seri Pembelajaran Inovatif. Konsep, Miskonsepsi dan Cara Pembelajarannya. Surabaya: Unesa University Press

Imamah, N. (2012). Peningkatan Hasil Belajar IPA Melalui Pembelajaran Kooperatif Berbasis Konstruktivisme Dipadukan dengan Video Animasi Materi Sistem Kehidupan Tumbuhan. Jurnal Pendidikan IPA Indonesia. http://journal.unnes.ac.id/index.php/jpii. JPP1 (1)(2012)32-36. Diakses tanggal 5 Februari 2016

Kemendikbud. (2014). Modul Pelatihan Implementasi Kurikulum 2013. Materi Pelatihan Guru Implementasi Kurikulum 2013 Tahun Ajaran 2014/2015 Mata Pelajaran Ipa Smp/MTs. Jakarta: Badan Pengembangan Sumber Daya Manusia Pendidikan dan Kebudayaan dan Penjaminan Mutu Pendidikan Kementerian Pendidikan dan Kebudayaan Republik Indonesia.

Kemendikbud. (2014). Peraturan Menteri Pendidikan Dan Kebudayaan Republik Indonesia Nomor 103 Tahun 2014 Tentang Pembelajaran pada Pendidikan Dasar dan Pendidikan Menengah. Jakarta: Menteri Pendidikan Dan Kebudayaan Republik Indonesia.

Makoolati, N., Amini, M., Raisi, H., Yazani, Sh. Razeghi, AV. (2015). The Effectiveness of Guided Discovery Learning On The Learning And Satisfaction of Nursing Students. Hormozgan Medical Journal, Vol 18, No.6. hmj.hums.ac.ir/article-1-1434-fa.pdf. Diakses tanggal 30 Mei 2016.

Nur dan Wikandari, P.R. (2000). Pengajaran Berpusat Kepada Siswa dan Pendekatan Konstruktivis dalam Pengajaran. Surabaya : Unesa.

Oloyede, O.I., (2010). Comparative Effect of the Guided Discovery and Concept Mapping Teaching Strategies on Students' Chemistry Achievement. Humanity \& Social Sciences Journal 5 (1):01-06, 2010. ISSN 1818-4960. www.idosi.org./hssj/hssj5(1)10/1.pdf. Diakses tanggal 30 Mei 2016.

Ratumanan, T. \& Laurens, T. (2011). Penilaian Hasil Belajar pada Tingkat Satuan Pendidikan. Surabaya: Unesa University Press.

Rustaman. (2010). Model-model Pembelajaran. Mengembangkan Profesionalisme Guru. Jakarta : Raja Grafindo Persada.

Sanjaya, W. (2006). Strategi Pembelajaran Berorientasi Standar Proses Pendidikan. Jakarta: Prenada Media Group.

Sari, N. (2014). Penerapan Media Animasi dalam Pembelajaran Biologi SMA Berbasis Contextual Teaching and Learning untuk Melatihkan Keterampilan Mengamati. Tesis tidak dipublikasikan. Program Studi Pendidikan Sains, Program Pascasarjana Universitas Surabaya.

Slavin, R.E. (1994). Educational Psychology: Theory and Practice. Massachusesttes: Allyn and Bacon Publishers.

Slavin, R.E. (2011). Psikologi Pendidikan Teori dan Praktik Edisi kesembilan Jilid I. Jakarta: Indeks.

Smaldino, S.E, Lowther, D.L., dan Russell, J.D. (2011). Instructional Technology \& Media for Learning. Tehnologi Pembelajaran dan Media untuk Belajar. Edisi Kesembilan. Jakarta: Penerbit Kencana Prenadamedia Group.

Sudjana, N dan Rivai, A. (2002). Media Pengajaran. Bandung : Sinar Baru Algensindo.

Suparno, P. (1997). Filsafat Konstruktivisme dalam Pendidikan. Yogyakarta: Kanisius.

Suryani, H. (2006). Pengembangan Perangkat Pembelajaran Ipa Berbasis Guided Discovery Learning Untuk Meningkatkan Keterampilan Proses Sains Di Smp Negeri 2 Kesamben. Tesis tidak dipublikasikan. Program Studi Pendidikan Sains, Program Pascasarjana Universitas Surabaya. 
Suryosubroto, B.(2009). Proses Belajar Mengajar di Sekolah. Jakarta: Rineka Cipta

Thiagarajan, S, Semmel, D.S., \& Semmel, M.I. (1974). Instructional Development for Training Teachers of Exceptional Children. Indiana: Indiana University.

Tipler, P.A. (2001). Fisika Untuk Sains dan Teknik Edisi Ketiga Jilid 2. Jakarta: Erlangga.

Windarti.(2013). Melatih Keterampilan Berpikir Kritis Menggunakan Metode Pembelajaran Penemuan Terbimbing (Guided Discovery) pada Siswa SMP. Jurnal Pendidikan Sains Pascasarjana UNESA. Vol 3. No 1. November 2013 p. 274-278 